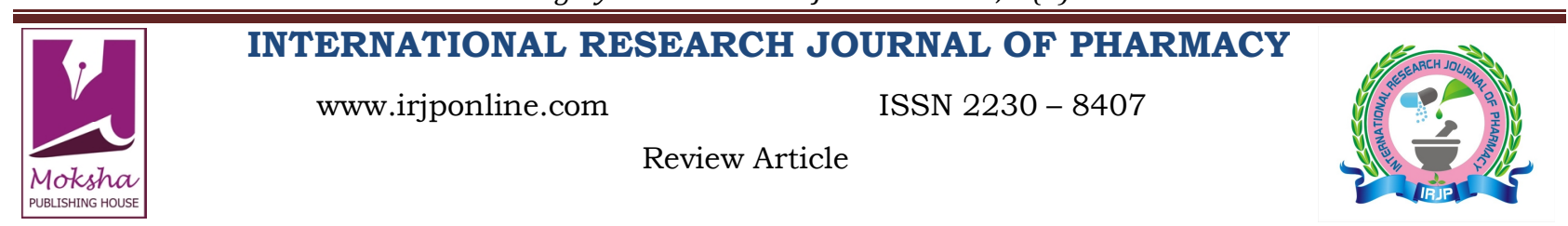

\title{
IMPLICATIONS FOR SUPPLEMENTATION OF DIETARY ENZYMES IN POULTRY FEED: A REVIEW
}

Ganguly Subha*

AICRP on Post Harvest Technology (ICAR), Department of Fish Processing Technology, Faculty of Fishery Sciences, West Bengal University of Animal and Fishery Sciences, 5, Budherhat Road, P.O. Panchasayar, Chakgaria, Kolkata - 700 094, WB, India

*Corresponding Author Email: ganguly38@gmail.com

Article Received on: 28/03/13 Revised on: 01/04/13 Approved for publication: 01/05/13

DOI: 10.7897/2230-8407.04503

IRJP is an official publication of Moksha Publishing House. Website: www.mokshaph.com

(C) All rights reserved.

\section{ABSTRACT}

The present review highlights the effect of dietary enzyme supplementation on different body growth parameters of poultry birds at their various growing stages. The article stresses on the effect of dietary enzymes on various physiological parameters of the poultry birds along with their application as growth promoters in commercial poultry feed.

Key words: feed, prebiotics, poultry

\section{INTRODUCTION}

Xylanase is the name given to a class of enzymes which degrades the linear polysaccharide beta-1, 4 xylan to xylose, thus breaking down hemicelluloses which are a major component of the cell wall of the plants. Xylanases are known to increase protein digestibility of wheat and this is attributed particularly to release of protein from the xylan enriched aleurone layer. Xylanase supplementation improves conjugated bile acid function in intestinal contents and increase villus size of small intestine wall in broiler. Supplementing broiler diets with combination of xylanase and $\beta$-glucanase improves the nutritive value of the $\operatorname{diet}^{1}$. The addition of xylanase improves weight gain, feed intake, feed efficiency, AME and decreased water intake ${ }^{2}$ and Vitamin E content of liver in broiler was significantly improved by addition of xylanase ${ }^{3}$. Nutri-xylanase is a bacterial xylanase processed from Bacillus subtilis and produced by a microfiltration advanced fermentation technique.

\section{Effect on body weight gain and feed efficiency}

Bar et al. ${ }^{4}$ conducted an experiment to study the effect of xylanase enzyme on body parameters of broiler birds. The experimental birds were distributed into five equal groups including control. Studies on body weight gain revealed that at the end of $4^{\text {th }}$ week of experiment, significant difference in body weight gain among the birds of the control and various treatment group was noticed $(\mathrm{P}<0.05)$ though there was subtle difference among the birds of control and various treatment groups $\left(T_{1}-T_{4}\right)$. Birds of $T_{3}$ group revealed the highest body weight gain followed by the birds of $T_{1}, T_{2}$ and $\mathrm{T}_{4}$ groups respectively. Birds of the control group revealed the lowest body weight gain. At the end of $5^{\text {th }}$ and $6^{\text {th }}$ week of experiment there was significant difference $(\mathrm{P}<0.05)$ in the body weight gain among the birds of the control and various treatment group. Birds of $\mathrm{T}_{3}$ group revealed the highest body weight gain and the lowest body weight gain were observed in the birds of control group.

Establishment of fact through research and investigations Mannion ${ }^{5}$ reported that the body weight gain was improved by $12-25 \%$ and feed consumption was increased by $3-21 \%$ when chicks at 4 weeks of age fed diets supplemented with enzyme like xylanase. Veldman and $\mathrm{Vahl}^{1}$ noticed xylanase supplementation improved food conversion ratio by $2.2-2.9 \%$ and body weight gain by $0.2-2.5 \%$. Silverslides and Bedford ${ }^{6}$ showed xylanase supplementation had a positive body weight gain and the feed to gain ration. Danicke et al. ${ }^{3}$ found addition of xylanase significantly increased the weight gain up to 21 days of age and decreased the feed to gain ratio slightly. Mathlouthi et al. ${ }^{7}$ showed feed efficacy and body weight gain was improved with the supplementation of xylanase.

Wu et al. ${ }^{2}$ (2004) observed that the xylanase supplementation significantly improved weight gain, feed efficiency and AME. Wu et al. ${ }^{2}$ observed that addition of xylanase and phytase reduced the relative weight gain of the small intestine by $15.5 \%$ and $11.4 \%$ respectively. Yubo et al. ${ }^{8}$ reported body weight and feed per gain ratio was improved $(\mathrm{P}<0.05)$ by xylanase supplementation in the first 2-3 weeks in broilers. Ahmad et al. ${ }^{9}$ noticed xylanase supplementation increased body weight, feed intake and feed gain ratio. Liu et al. ${ }^{10}$ observed xylanase supplementation increased body weight gain from 0-21 days of age of broilers. Gao et al. ${ }^{11}$ found that the supplementation of xylanase enzyme improved $(\mathrm{P}<0.05)$ growth performance and feed conversion efficiency (FCE).

\section{SUMMARY}

It can therefore be summarized that supplementation of poultry feed with dietary enzymes in proper combinations can enhance the feed efficiency of the host by showing increased body weight gain.

Supplementation of poultry feed with dietary supplements such as acids, pre- and probiotics can enhance the immune system of the host by providing increased resistance to infections. This, in turn, can promote gut development and nutrient absorption, leading to better performance. ${ }^{12,13,14}$

\section{REFERENCES}

1. Veldman A, Vahl HA. Xylanase in broiler diets with differences in characteristics and content of wheat. British Poultry Science 1994;35(4):537-50. http://dx.doi.org/10.1080/00071669408417719 PMid:7828012

2. Wu YB, Ravindran V, Thomas DG, Birtles MJ, Hendriks WH Influence of phytase and xylanase individually or in combination, on performance, apparent metabolizable energy (AME), digestive tract measurements and gut morphology in broilers fed wheat based diet containing adequate 
level of phosphorus. British Poultry Science 2004:45:76-84. http://dx.doi.org/10.1080/00071660410001668897 PMid:15115204

3. Danicke S, Halle I, Franke A, Jeroch H Effect of energy source and xylanase addition on energy metabolism, performance, chemical body composition and total body electrical conductivity (TOBECO) of broilers. Animal Physiology and Animal Nutrition 2001;85(9-10):30113. http://dx.doi.org/10.1046/j.1439-0396.2001.00318.x

4. Bar N, Mukhopadhayay SK, Ganguly S, Pradhan S, Patra NC, Pal S, Goswami J, Singh YD, Halder S. Study on probiotic effect of xylanase supplementation in broiler feed. Indian J Anim Nutr 2012;29(1):100-03.

5. Mannion PF. Enzyme supplementation of barley based diets for broiler chickens. Australian Journal of Experimental Agriculture and Animal Husbandry 1981;21:296- 302. http://dx.doi.org/10.1071/EA9810296

6. Silverslides FG, Bedford MR. Effects of pelleting temperature on the recovery and efficiency of a xylanase enzyme in wheat based diet. Poultry Science 1999;78:1184-90.

7. Mathlouthi N, Junin H, Larbier M. Effects of xylanase and betaglucanase supplementation of wheat or wheat and barley based diets on the performance of male turkeys. British Poultry Science 2003;44(2):291-98. http://dx.doi.org/10.1080/0007166031000096498 PMid: 12828215

8. Yubo WB, Changhua L, Shiyan Q, Limin G, Wenqing L, Defali. Properties of Aspergillus xylanase and the effects of xylanase supplementation in wheat based diets on growth performance and the blood biochemical values in broilers. Asia Australian Journal of Animal Science 2005;18:66-74.
9. Ahmad K, Michael B, Abdolreza K, Mohamad M. Comparative Effects of xylanase supplementation on broiler, Broiler Breeder and Layer Chick Performance and Feed Utilization on Wheat Based Diet. Japan Poultry Science 2007;44:322-29. http://dx.doi.org/10.2141/jpsa.44.322

10. Liu JR, Lai SF, You B. Evaluation of an Lactobacillus reuteri strain expressing rumen fungal xylanase as a probiotic for broiler chickens fed on wheat based diet. British Poultry Science 2007;48(4):507-14. http://dx.doi.org/10.1080/00071660701485034 PMid:17701504

11. Gao F, Jiang Y, Zhou GH, Han ZK. The effect of xylanase supplementation on performance characteristics of G.I. Tract, blood parameters and gut microflora in broiler feed on wheat based diet. Animal Feed Science and Technology 2008;142:173-84. http:// dx.doi.org/10.1016/j.anifeedsci.2007.07.008

12. Ganguly S, Paul I, Mukhopadhayay SK Immunostimulant, probiotic and prebiotic - their applications and effectiveness in aquaculture: A Review. Israeli J Aquacult - Bamidgeh 2010;62(3): 130-38.

13. Ganguly S, Dora KC, Sarkar S, Chowdhury S Supplementation of prebiotics in fish feed- A Review. Rev Fish Biol Fisheries 2013;23(2): 195-99, http://dx.doi.org/10.1007/s11160-012-9291-5

14. Ganguly S. Supplementation of prebiotics in poultry feed- A Review. World's Poult Sci J 2013; doi 10.1017/1 S0043933913000640. In press.

Cite this article as:

Ganguly Subha. Implications for supplementation of dietary enzymes in poultry feed: A review. Int. Res. J. Pharm. 2013; 4(5):10-11 